\title{
TEOLOGÍA POLÍTICA Y FACTORES ESENCIALES EN EL DESARROLLO DE LA PROVINCIA ECLESIÁSTICA MEXICANA: UNA PROPUESTA DESDE LAS RELACIONES DE VISITA AD LIMINA APOSTOLORUM: 1585-1800
}

\author{
POR \\ MisAel CAMUS IBACACHE ${ }^{1}$ \\ Universidad de Tarapacá
}

\section{RESUMEN}

El artículo propone que en la génesis que impulsó la maduración de las estructuras eclesiales en la provincia eclesiástica mexicana, hay cuatro factores esenciales, a saber: la autonomía de la expansión eclesial territorial; el rol social y político de los capítulos catedralicios; el desarrollo complejo de un sistema educativo escolar, medio y superior; y, el desarrollo inédito del carácter religioso mariano, cuya base fueron dos tradiciones del culto a María: la Inmaculada Concepción y la Asunción. La investigación se sostiene en la revisión y sistematización de información en fuentes primarias, como son las Relaciones de visita ad limina enviadas por los obispos de esta provincia a Roma. El estudio resalta la teología política en el desarrollo eclesial, que define la sociedad política como la expresión de la unicidad de la esfera secular y eclesiástica, que hace emerger el dominium de ecclesia, en este caso, Iglesia y Monarquía, la cual se canalizó y concretizó, a través de la articulación de las reformas del Concilio de Trento con las Leyes patronales.

PALABRAS CLAVE: Visita ad limina Apostolorum; provincia eclesiástica; estructura eclesial; Concilio de Trento; período colonial mexicano.

\section{POLITICAL THEOLOGY AND ESSENTIAL FACTORS IN THE DEVELOPMENT OF THE MEXICAN ECCLESIASTICAL PROVINCE: A PROPOSAL FROM THE RELATIONS OF VISITA AD LIMINA APOSTOLORUM: 1585-1800}

\begin{abstract}
The article proposes that in the genesis that drove the maturation of the clerical structures in the Mexican ecclesiastical province, there are four essential factors, specifically: the autonomy of the territorial ecclesiastical expansion; the social and political role of the cathedral chapters; the complex development of a school, middle and higher education system; and, the unprecedented development of the Marian religious character, which basis were two traditions of the cult of Mary: the Immaculate Conception and the Assumption of the virgin. The research is based on the review and systematization of information from leading sources, such as the Ad Limina Visitor's Reports sent by this province's bishops to Rome. The study highlights the political theology in ecclesial development, which defines political society as the expression of the secular and ecclesiastical sphere's uniqueness. These make emerging the dominium of the ecclesia, in this case, Church and Monarchy, which was channeled and made tangible through the articulation of the Council of Trent's reforms with the employers' laws.
\end{abstract}

KEY WORDS: Ad limina Apostolorum visit; ecclesiastical province; ecclesiastical structure; Council of Trent; Mexican Colonial Period.

Cómo CitAR ESTE ARTículo / CitATION: Camus Ibacache, Misael. 2021. «Teología política y factores esenciales en el desarrollo de la provincia eclesiástica mexicana: una propuesta desde las Relaciones de Visita ad limina apostolorum: 1585-1800». Hispania Sacra LXXIII, 147: 175-189. https://doi.org/10.3989/hs.2021.016

$\begin{array}{ll}\text { Recibido/Received } & 06-12-2019 \\ \text { Aceptado/Accepted } & 06-10-2020\end{array}$

1 misaelhcamus@gmail.com / ORCID ID: https://orcid.org/0000-0002-6817-2955 


\section{INTRODUCCIÓN}

El desarrollo de la provincia eclesiástica mexicana manifiesta aportes significativos, tanto en su devenir particular como para la región hispánica en su conjunto. Evidencias de este proceso de maduración sostenido fueron la consolidación de la devoción de la Virgen de Guadalupe, que fue declarada patrona de la ciudad en 1637 y de la provincia en 1754 y en 1910 de América Latina; y el temprano tránsito desde un episcopado de clérigos regulares a otro de seculares.

Este proceso histórico se materializó a través de la unidad entre la esfera civil y eclesiástica, del cual emergió el concepto dominium de ecclesia, es el que se utiliza en este estudio, en un sentido amplio y sistémico de la sociedad política medieval, como lo describe Saskia Sassen $(2009)^{2}$ al afirmar que:

Durante el feudalismo, hubo una especie de autoridad central que emana de la Iglesia y del Imperio. Pero esta no está fundada en una autoridad territorial exclusiva. Las formas de autoridad de la Iglesia y del Imperio podían coexistir con las jurisdicciones feudales, y entre ellas, aun si los conflictos fueren frecuentes. Desde esta visión universal, ambas entidades no podían tolerar ninguna otra autoridad en sus dominios respectivos...

O, como señala Le Goff: «En esta sociedad, dominada, impregnada hasta las más finas o íntimas fibras por la religión, un tal modelo, evidentemente, era definido por la religión»; o, para mayor precisión, cuando afirma que

\begin{abstract}
la noción de creación se vincula con una concepción de Dios, la naturaleza y el hombre. La coherencia se mantiene, se organiza y se reorganiza por acción de un organismo, en sí mismo, coherente: la Iglesia. Se corresponde con esto una sociedad jerárquica, centrada en torno al dominium: el dominio, el señorío. El dominium inserta - encarna - la función divina de la sociedad.
\end{abstract}

En su temporalidad, como la sintetiza Ribot (2019), al sostener que en el tiempo de la Edad Moderna la concepción de la vida y de la existencia no ha variado con relación a la época medieval, afirma:

Desde el nacimiento a la muerte, era la iglesia, a través de los sacramentos o de prácticas piadosas, la que regulaba los diversos momentos y circunstancia: la entrada en la comunidad, los diferentes ritos de paso, la despedida y el entierro, además, naturalmente, de la práctica sacramental ordinaria (penitencia y eucaristía). Las disposiciones tridentinas establecieron un riguroso control de los fieles, que tenía su correlato en diversas iglesias protestantes... Todo ello redundó en un enorme poder del clero, pues la sacralización de la existencia había generado una sociedad fuertemente clericalizada.

Este modelo político se canalizó en América Latina desde dos fuentes ordenadoras: las reformas del Concilio de Trento (en adelante, Concilio) y las Leyes Patronales, lugar jurídico secular donde se produjo la recepción del Concilio.

La ubicación geográfica de la provincia eclesiástica jugó un rol diferenciador, pues ella encontró de forma natural sus límites, luego, el espacio centroamericano profundizó esa

2 Sassen 2009, 16-17; Le Goff 2005, 11; 2003, 90; Ribot Luis 2019, 103. condición, de este modo en el territorio de la Nueva España se logró la mejor unidad entre la jurisdicción eclesial y la secular.

En este horizonte, el estudio busca individualizar y comprender los factores que impulsaron el desarrollo de esta provincia. Las fuentes primarias serán los documentos del cumplimiento de la norma de visita ad limina apostolorum, en particular las Relaciones enviadas por algunos obispos que cumplieron con la bula de Sixto V, de 1585, la que les obligaba a: visitar las Basílicas de San Pedro y San Pablo, expresar fidelidad al sucesor de Pedro y, presentar una Relación sobre el estado de la iglesia. ${ }^{3}$ Las iglesias latinoamericanas debían cumplirla cada diez años.

Sobre la práctica de visita ad limina de los obispos mexicanos se conocen cuatro estudios en los últimos setenta años, estos son: Mariano Cuevas en su Historia de la Iglesia en México ofrece antecedentes sobre seis relaciones diocesanas de distintas diócesis y concentradas en el siglo XVIII; María Milagros Cárcel Ortí (1988) elaboró una nómina de la visita ad limina por cada diócesis de Hispanoamérica, que fue publicado por la Universidad de Valencia. En 1993 la Collection de l'École française de Rome-293, organizó un Coloquio sobre la visita ad limina, que fue publicado en 2002. El investigador Jean-Pierre Berthe (2002) presentó las Relaciones diocesanas de visita ad limina de los obispos de Nueva España en los siglos XVI-XVIII. Finalmente, el autor de este trabajo, publicó en 1994, en Hispania Sacra - vol. XLVI, $\mathrm{n}^{\circ}$ 93- un nuevo registro y observaciones sobre el comportamiento de los obispos latinoamericanos respecto a la norma.

Los resultados de esta investigación se organizan en cuatro apartados: primero, caracteriza la estructura de la iglesia, desde la mirada pastoral del Concilio -episcopado, cabildo, clero...- pues, es esta estructura la que se explicita en toda Relación diocesana; segundo, evalúa el conjunto documental del proceso de visita ad limina; tercero, articula los contenidos de las Relaciones, para caracterizar la maduración institucional de las diócesis; cuarto, las conclusiones sistematizan la relación entre los factores de desarrollo de la provincia eclesiástica, con la concepción de la sociedad política basada en la unidad entre Iglesia y Monarquía, que permitió que el dominium de ecclesia, se canalizara y concretara, a través de la articulación de las reformas del Concilio y las Leyes Patronales.

\section{EVOLUCIÓN DE LA ESTRUCTURA ECLESIAL Y LA RECEPCIÓN DEL CONCILIO: 1546-1800}

Este apartado ofrece un análisis de algunas variables en la gestión eclesial y de algunos órganos nacidos o reformados por el Concilio. Estos contenidos permitirán una aproximación hermenéutica al relato de la Relación, en cuanto que ella es el resultado de la auditoría, que el obispo ejecutó a las estructuras y órganos de la iglesia.

3 Una referencia historiográfica obligada para conocer el desarrollo de esta norma: Cárcel Ortiz y Cárcel Ortiz 1990. La primera parte está dedicada al desarrollo histórico jurídico de este precepto hasta el derecho eclesial actual. 
Previamente, será útil una descripción a la dinámica fundacional de las diócesis, cuya expansión territorial fue muy acelerada.

Las dos primeras diócesis erigidas están al centro del territorio: Puebla 1525 y México en 1530; Michoacán en 1535 al norte y Oaxaca en 1536 al sur; y, en el límite con la capitanía de Guatemala, se fundó Chiapas, en 1536; más tarde, en 1548 Guadalajara, se avanzó al oeste, por el norte y mirando hacia la costa; Yucatán al sur-este, e inserta en la península homónima, se erigió en 1561. En treinta y seis años -1525-1561se erigieron siete diócesis, proceso que incluye la elevación de México a metropolitana, en 1546. En el año 1620 terminó la expansión evangelizadora, con la fundación de Durango.

A continuación, se estudian variables en la gestión diocesana, como factores del desarrollo institucional.

\subsection{La procedencia clerical de los obispos: religiosos y seculares}

Los obispos procedían del clero religioso o secular, pero la política patronal eclesial tendió tempranamente a instalar prelados seculares, de este modo la relación era directa corona-obispo-clero, se evita una autoridad intermedia, esto es, los superiores generales y la acción pastoral se tornaba más expedita. La perspectiva de esta sección es conocer la dinámica de la distribución de los obispos según procedencia clerical. La elaboración de la tabla muestra esa dinámica por siglos. ${ }^{4}$

TABLA 1

Distribución de la procedencia de los obispos: religiosa o secular $(R / S)$

\begin{tabular}{|l|c|c|c|c|}
\hline \multicolumn{1}{|c|}{ Diócesis } & $\begin{array}{c}\text { S. } \mathbf{X V I} \\
\mathbf{R} / \mathbf{S}\end{array}$ & $\begin{array}{c}\text { S. } \mathbf{X V I I} \\
\mathbf{R} / \mathbf{S}\end{array}$ & $\begin{array}{c}\text { S. } \mathbf{X V I I I} \\
\mathbf{R} / \mathbf{S}\end{array}$ & $\begin{array}{c}\text { Total } \\
\mathbf{R} / \mathbf{S}\end{array}$ \\
\hline México & $2 / 1$ & $2 / 11$ & $1 / 6$ & $5 / 18$ \\
\hline Puebla & $3 / 3$ & $0 / 6$ & $0 / 10$ & $3 / 19$ \\
\hline Michoacán & $3 / 1$ & $3 / 7$ & $0 / 11$ & $6 / 19$ \\
\hline Chiapas & $4 / 0$ & $6 / 2$ & $4 / 6$ & $14 / 8$ \\
\hline Oaxaca & $2 / 1$ & $5 / 5$ & $1 / 7$ & $8 / 13$ \\
\hline Guadalajara & $3 / 2$ & $3 / 7$ & $2 / 8$ & $8 / 17$ \\
\hline Yucatán & $4 / 0$ & $3 / 7$ & $6 / 5$ & $13 / 12$ \\
\hline Durango & ---- & $4 / 5$ & $2 / 10$ & $6 / 15$ \\
\hline Totales & $\mathbf{2 1 / 8}$ & $\mathbf{2 6 / 5 0}$ & $\mathbf{1 6 / 6 3}$ & $\mathbf{6 3 / 1 2 1}$ \\
\hline
\end{tabular}

La tabla permite constatar que: los obispos religiosos predominaron en la fase de instalación en el s. XVI, en una relación $72,4 \%$ religiosos y $27,6 \%$ seculares; en el s. XVII los obispos religiosos representan el $34 \%$; en el s. XVIII los obispos seculares alcanzan el 79,7\%. La diócesis de Chiapas tuvo un proceso más lento.

\subsection{El traslado de los obispos: movilidad episcopal en clave de eficiencia pastoral}

La sede vacante es generada por deceso, traslado o renuncia del obispo. Ahora bien, el problema surgió por el tiempo que demoraba entre la presentación del clérigo al

$4 \quad$ Los antecedentes de la sucesión episcopal fueron extraídos de la Hierarquia Catholica Medii et Recentioris Aevi, vol. III, Patavii 1960²; vol. IV, Patavii 1947; vol V, Patavii 1952 y vol. VI, Patavii 1958. episcopado y la toma de posesión de la diócesis - uno a dos años-, la medida para agilizarlo fue la política de tomar posesión "por ruego y encargo». Al dar seguimiento a la sucesión episcopal se descubre que la vacancia también se resolvió con una política más eficiente: proveerlas con traslado de obispos entre diócesis de la misma región. Con esta política surgieron diócesis proveedoras y otras receptoras. Un ejemplo de diócesis «receptora» fue Puebla, en el s. XVII: dos obispos trasladados desde Guadalajara cubrieron 42 años y, en el s. XVIII los trasladados desde Santa Fe, Michoacán, Durango y Cuba cubrieron 21 años, y el traslado del arzobispo de Santo Domingo, cubrió otros 20 años. En 200 años la sede vacante se resolvió en un $40 \%$ con traslados de obispos. Es importante subrayar que esta política aportó estabilidad al ministerio episcopal.

\subsection{La metropolitana: un caso excepcional de gestión}

Este subpunto plantea que, por una parte, la diócesis metropolitana evidencia cómo la sucesión episcopal irregular impactó en su desarrollo; y, cómo los periodos regulares sostienen su desarrollo; además, la irregularidad interrumpió la práctica de la visita ad limina entre 1614 hasta 1694. Esta dinámica afectó el gobierno en una comunidad en proceso de maduración, se agudizó la ausencia de la visita pastoral y se postergó la erección del seminario hasta fines del s. XVII. El desarrollo de la metrópolis dependió de la sucesión episcopal fundacional del s. XVI y, aquella desde fines del XVII; y, de un cabildo catedralicio robusto.

A continuación, se estudia la sucesión episcopal en la metropolitana, para ello se usa un episcopologio elaborado en el s. XIX. ${ }^{5}$

Los obispos del s. XVI gobiernan en promedio 18 años: Juan Zumarraga OM, 18 años; Alfonso de Montufar OP, 20; Pedro Moya de Contreras, 17. Con el obispo Alfonso Fernández de Bonilla se cierra el siglo con un gobierno de cuatro años; desde 1629 a 1667 hay 10 obispos; sólo a fines del s. XVII, con Fr. Payus Enríquez (1668-1680) se inició un nuevo periodo de estabilidad episcopal de 130 años, hasta terminar el s. XVIII. Los prelados son: Juan Ortega y Montañez (1699-1710) 11 años; José Lanciego y Eguilaz (1712-1728) 16 años; Juan de Vizarrón (1730-1747) 17 años; Emmanuel Rubio y Salinas (1749-1765) 16 años y, Alfonso Núñez de Haro (1771-1800) 29 años.

En estos 130 años la metrópolis profundizó un crecimiento sistémico de la vida eclesial: una red parroquial sólida, el santuario de María de Guadalupe deviene el centro devocional de la provincia, el cabildo eclesiástico pasa a ser espacio de movilidad eclesial criolla y, el seminario el centro para la formación del clero.

\subsection{Dos reformas del Concilio como factores de desarrollo eclesial: las congregaciones nuevas y el cabildo catedralicio}

A las congregaciones mendicantes, se sumaron los jesuitas; sin menoscabar la relevancia de ellas, las nacidas del espíritu de Trento -Oratoriano, oblato de San Carlos, San

La sucesión episcopal de la diócesis de México es la transcripción de la elaborada por el arzobispo Próspero Alarcón y Sánchez, que incluyó en la Relación, en cumplimiento de visita ad limina del año 1897, cf. Archivo Apostólico Vaticano (AAV). Relaciones diocesanas de México, caja 450 
Camilo- y, la constitución del cabildo catedralicio reformado, se constituyeron en factores que consolidaron la vida eclesial en esta provincia. ${ }^{6}$

\section{- Las congregaciones nuevas}

La congregación oratoriana fue la que alcanzó mayor penetración eclesial. Las Relaciones permiten esbozar la obra pastoral de estos religiosos, la que abarcó desde administrar parroquias, dirigir el seminario hasta gestionar obras asistenciales; expertos en catequesis, a través de las Escuelas de Cristo y, en la Universidad. ${ }^{7}$

Una arista a considerar en la historia de los oratorianos en México, es distinguir entre la congregación y la asociación Venerable Unión inspirada en el carisma de Felipe Neri. Por ello, que individualizar ambas instituciones es esencial para no confundir las obras eclesiales. Estudios que articulen su expansión son incipientes y, no sólo a nivel de la provincia mexicana sino incluyendo las diócesis de Guatemala y Lima. ${ }^{8}$

\section{- El cabildo catedralicio}

La reforma conciliar del cabildo corrigió vicios, como: acumulación de beneficios, ausentismo, posición de dominio en relación al obispo; la relación del cabildo con el obispo, los requisitos para acceder a las dignidades y prebendados y de la formación de sus miembros. En este sentido, la reforma reguló las funciones litúrgicas, las benefactoras y administrativas del organismo; incrementó el poder del obispo sobre el cabildo, sin descuidar su autonomía, para lo cual, precisó que el obispo debía respetar el Estatuto del organismo y le entregó una función de gestión en sede vacante; de esta norma surgieron los Vicarios capitulares. ${ }^{9}$

Estas reformas del cabildo fueron claves para la maduración de estas iglesias, pues de las funciones de administración y gobierno dependieron asuntos de patrimonio, de culto e influencia en los espacios culturales y un lugar estratégico del desarrollo del clero criollo.

\section{DE LA PRÁCTICA DE VISITA AD LIMINA DE LAS DIÓCESIS MEXICANAS: $1585-1800$}

Este apartado presenta las fuentes primarias del estudio, se subraya la frecuencia, el procedimiento del cumplimiento de la norma y los actores. Las fuentes son aquellas conservadas en el Archivo Apostólico Vaticano. ${ }^{10}$

\footnotetext{
6 Un estudio que muestra la transversalidad del factor cabildo, cf. Enríquez Agrazar 2006.

7 Benjamín 2018. El autor desarrolla con cierto detalle la historia de la Venerable Unión Oratoriana. Bazarte Martínez y Cruz Rangel 2009.

8 La Relación del arzobispo Liñán y Cisneros de Lima de 1690, registra la presencia oratoriana, cf. AAV. Relaciones diocesanos de Lima, caja $n^{\circ}$ 450. La Relación de 1717 del obispo de Guatemala, registra a los oratorianos dirigiendo el seminario, cf. AAV. Relaciones diocesanas de Guatemala, caja $\mathrm{n}^{\circ} 384$. Estas evidencias precisan la dinámica de la expansión oratoriana: Ilegaron a Puebla 1669, Lima 1683, Guatemala 1689, México 1697.

9 Granado Hijelmo 2010. Es un estudio que sitúa las definiciones previas al Concilio de Trento, las reformas que promulgó y ofrece una foto precisa de la praxis de la reforma del órgano, en una diócesis concreta con más de un capitulo. Cf. Pérez Puente y Castillo Flores 2016. Es una obra colectiva que, en varios artículos aborda la relación del capítulo con el poder secular y eclesial.

10 AAV. Relaciones diocesanas de la Provincia Eclesiástica de México 1585-1800. Fondo Congregación del Concilio. Las referencias son:
}

\subsection{La frecuencia}

Esta tabla ofrece un panorama desde la frecuencia del cumplimiento de la norma. Para su datación se ha considerado la fecha más antigua registrada en la diócesis, por lo general es aquella registrada en la Relación, en los casos que ella no exista, se optó entre aquella anotada en el poder del obispo al procurador o en la carta del obispo al pontífice.

TABLA 2

Frecuencia de la visita ad limina de la provincia eclesiástica mexicana

\begin{tabular}{|c|c|c|c|c|}
\hline Diócesis & $\begin{array}{c}\text { S. XVI } \\
(1585-1599)\end{array}$ & $\begin{array}{c}\text { S. XVII } \\
(1600-1699)\end{array}$ & $\begin{array}{c}\text { S. XVIII } \\
(1700-1799)\end{array}$ & Total \\
\hline $\begin{array}{l}\text { México } \\
1530 \\
\text { metropoli- } \\
\text { tana } 1546\end{array}$ & ----- & $\begin{array}{c}1615- \\
1693 / 1695 \text { (a) }\end{array}$ & $1703-1720-1761$ & 5 \\
\hline $\begin{array}{l}\text { Tlaxcala/ } \\
\text { Puebla } \\
1525\end{array}$ & $1594^{11}$ & $\begin{array}{l}1647-1660- \\
1681-1691\end{array}$ & $1708-1731-1750$ & 8 \\
\hline $\begin{array}{l}\text { Michoacán } \\
1535\end{array}$ & ----- & 1616 & 1752 & 2 \\
\hline $\begin{array}{l}\text { Chiapas } \\
1536\end{array}$ & ----- & $\begin{array}{c}1609-1690- \\
1699\end{array}$ & $\begin{array}{c}1722(b)-1742 \\
1763-1767-1792\end{array}$ & 8 \\
\hline $\begin{array}{l}\text { Oaxaca/An- } \\
\text { tequera } \\
1536\end{array}$ & 1592 & $\begin{array}{c}1648-1678- \\
1688\end{array}$ & 1772 & 5 \\
\hline $\begin{array}{l}\text { Guadalajara } \\
1548\end{array}$ & ----- & $\begin{array}{c}1632-1656- \\
1692\end{array}$ & $\begin{array}{l}1734-1754- \\
1757-1781\end{array}$ & 7 \\
\hline $\begin{array}{l}\text { Yucatán } \\
1561\end{array}$ & ----- & 1615- 1694 & $\begin{array}{c}1703-1720- \\
1733-1760- \\
1770\end{array}$ & 7 \\
\hline $\begin{array}{l}\text { Durango } \\
1620\end{array}$ & ----- & $1699^{12}$ & $\begin{array}{c}1703-1716- \\
1722-1726- \\
1742-1765-1778\end{array}$ & 8 \\
\hline Total & 2 & 19 & 29 & 50 \\
\hline
\end{tabular}

Nota: a = México, el obispo Francisco de Aguilar y Seixas explica que la Relación llegó con retraso por problemas de navegación, por lo cual se contabiliza solo una. Nota: $b=$ Chiapas, esta diócesis registra 8 veces en el cumplimiento del precepto.

La inclusión de las 8 visitas que cumplieron los obispos de Chiapas cubre el periodo como sufragánea de México y de Guatemala (en 1848 retornó a sufragánea de México). Esta decisión permitirá percibir su desarrollo en una unidad temporal.

México, caja 520; Puebla, caja 804; Michoacán, caja 507; Chiapas, caja 318; Oaxaca, caja 55; Guadalajara, caja 507; Yucatán, caja 421; Durango caja 302.

11 AAV. Registro VV. SS. LL., $\mathrm{n}^{\circ} 2$ : 1593-1601. Fondo Congregación del Concilio, folio 32. Se registró la visita del procurador del obispo de Puebla, el presbítero Pedro Morales.

12 La visita ad limina se realizó en 1701, el documento del obispo está fechado en Durango, en 1699. De esta manera se corrige la data de la visita, usando la data anotada en la diócesis. 
Las frecuencias más altas son de las diócesis Puebla, Chiapas y Durango; Puebla y Oaxaca cumplen con la norma tempranamente; Durango es una excepción dado que en el s. XVIII cumple casi decenalmente, como lo exigía la norma.

\subsection{El procedimiento: obispos, procuradores y documentos ${ }^{13}$}

La Relación es el documento central para conocer el estado de la iglesia, pero hay "otras fuentes» que ofrecen datos de personas, procedimientos e instituciones involucradas en el proceso. Estas "otras fuentes» como: la carta del obispo al pontífice precisa la procedencia geográfica, traslados y las causas que impiden realizarla personalmente; el poder dado al procurador individualiza los vínculos clericales y civiles; los certificados de las Basílicas certifican el tiempo que tomó cumplir la norma y el procurador que la ejecutó.

De los obispos que cumplieron 50 veces la norma, 36 son clérigos seculares y 14 religiosos; 7 criollos y 43 españoles. El s. XVIII fue efectivo, concentra el 58 \% (29 veces), bien distribuidas por diócesis. La norma se realizó sólo mediante procurador.

Los procuradores proceden mayormente del clero religioso: los jesuitas ejecutaron 23 veces la norma; varios obispos religiosos designaron a clérigos de sus órdenes; algunos obispos seculares y españoles dieron poder a clérigos que habitaban en España o en Roma, y son presentados como «mi agente en Roma». En 1690 el procurador Juan de Estrada S.J., representó a los obispos de Puebla, Guadalajara y Chiapas.

La diócesis de Durango muestra alta frecuencia y varios de los obispos trasladados volvieron a cumplirla: el arzobispo Juan Ortega Montañés (1700-1708), el periplo episcopal lo inició en Durango, pasó a Guatemala, Michoacán y terminó en México; el obispo García de Legazpi y Velasco inició su ministerio en Durango, gobernó 20 años, fue trasladado a Michoacán y terminó en Puebla; el obispo Martín de Elizacochea desde Durango pasó a Michoacán, en ambas cumplió con la norma.

Los obispos de Chiapas se caracterizan por gobiernos prolongados desde fines del s. XVII, fueron 110 años de estabilidad: (1682) 27 - 19 - 18 - 14 y 12 años (1800); cuatro son religiosos y 3 seculares; dos criollos; un obispo cumplió dos veces la norma. El desarrollo de Chiapas fue excepcional dada su cualidad de transfronteriza, la alta frecuencia de

13 Las referencias biográficas de los obispos, son las que ofrecen la documentación de visita ad limina, otras han sido recabadas en la Hierarquia Catholica Medii et Recentioris Aevi: vol. III-VI visita es prueba de un desarrollo autónomo y respuesta al desafío de la geografía extensa y extrema. ${ }^{14}$

Una práctica negativa fue la de Michoacán, la cumplió dos veces, comportamiento que contradice el desarrollo sostenido de la diócesis. ${ }^{15}$ En la Relación de 1754 se dice: "que jamás ha sido cumplida, atendiendo la gran distancia y otras urgentes causas, que le han retardado». El obispo desconoce que el obispo Baltazar de Covarrubias O. P. la cumplió en 1616.

Desde un análisis pastoral, el déficit en la práctica de la norma se podría explicar por dos variables vinculadas: la extensa jurisdicción y la movilidad episcopal impactaron en la gestión pastoral. En la elaboración de la Relación de visita ad limina, era imprescindible realizar la visita pastoral, la que en extensas jurisdicciones demoraba hasta un lustro; al sumar la movilidad episcopal, 90 \% de traslados, se generó un vacío de información, además de solaparse los decenios de la norma.

\section{EL ESTADO DE LA IGLESIA EN LA PROVINCIA MEXICANA, A TRAVÉS DE LAS RELACIONES}

En este apartado no sólo convergen los lineamientos metodológicos y eclesiológicos, sino que estos asumen una función de estructura hermenéutica, desde donde articular los contenidos de la Relaciones e ir caracterizando el estado de la iglesia. Para la presentación de los contenidos de las Relaciones se elaboraron tres tablas, las que agrupan y ordenan las diócesis por la eficiencia en el cumplimiento de la norma. Las diócesis de Puebla, Chiapas y Durango, ocho; Guadalajara y Yucatán, siete; y, México, Oaxaca y Michoacán, cinco y dos, respectivamente; por último, los contenidos siguen el orden que tienen las Relaciones.

\subsection{Contenidos en las Relaciones de Puebla, Chiapas y Durango}

Algunos antecedentes a subrayar de estas tres diócesis: Puebla es la iglesia primada, Durango es la última en ser erigida y Chiapas es una diócesis transfronteriza.

14 Viqueira Albán 2017. El estudio ofrece, con fuentes primarias, una visión general del desarrollo de este obispado. Las fuentes del estudio están transcritas y adjuntas como Anexos.

15 Brading 1994. El autor publicó originalmente esta obra en inglés: Church and State in Bourbon México, the Diocese of Michoacan 1749-1810. Posteriormente editó las fuentes de la obra junto a Oscar Mazín, titulándola: El gran Michoacán en 1791. Sociedad e ingreso eclesiástico en una diócesis novohispana. Estas fuentes permiten deducir la red parroquial al año 1791, la cual era de 127 unidades a cargo de seculares; a las que debieran agregarse otras cincuenta, a cargo de regulares. 
TABLA 3

Contenidos en las Relaciones de Puebla, Chiapas y Durango

\begin{tabular}{|c|c|c|}
\hline Diócesis Puebla: ${ }^{16}$ & Diócesis Chiapas: ${ }^{17}$ & Diócesis Durango: ${ }^{18}$ \\
\hline $\begin{array}{l}\text { Cabildo: en } 1594 \text { son } 5 \text { dignidades, } 12 \\
\text { canónigos y } 6 \text { porcioneros. El coro funciona a } \\
\text { diario. En } 1647 \text { él funciona normalmente. }\end{array}$ & $\begin{array}{l}\text { Cabildo: en } 1609 \text { con } 4 \text { dignidades y } 6 \text { canó- } \\
\text { nigos. } \\
\text { En } 1742 \text { dignidades } 4 \text {, un canónigo y } 6 \\
\text { capellanes de coro. En } 1763 \text { se mantiene la } \\
\text { estructura. }\end{array}$ & $\begin{array}{l}\text { Cabildo: en } 1728 \text { con } 3 \text { dignidades y cape- } \\
\text { llanes. }\end{array}$ \\
\hline $\begin{array}{l}\text { Visita pastoral: en } 1594 \text { se informa: } 16 \text { años } \\
\text { que no se hacía. En } 1647 \text { «la visita ha sido } \\
\text { realizada por siete años». En } 1731 \text { señala: se } \\
\text { ha realizado dos veces. }\end{array}$ & $\begin{array}{l}\text { Visita pastoral: en } 1742 \text { registra que: «a } \\
\text { pesar de la aspereza de los caminos no he } \\
\text { dejado de visitarle anualmente... ha logrado } \\
\text { consumir entre los indios la idolatría...» }\end{array}$ & $\begin{array}{l}\text { Visita pastoral: en } 1699 \text { se «ha realizado la } \\
\text { visita pastoral». En } 1726 \text { una referencia indi- } \\
\text { recta «ha confirmado } 5 \text { mil personas». }\end{array}$ \\
\hline $\begin{array}{l}\text { Parroquias: en } 1647 \text { la ciudad tiene } 4 \text { y en } \\
\text { la diócesis son } 104 \text { y otras inferiores y, } 19 \text { a } \\
\text { cargo de regulares. Total } 127 . \\
\text { En } 1731 \text { en la ciudad 5, curatos } 99 \text { con vica- } \\
\text { rios; entre los curatos, } 15 \text { entre los otomies, } \\
15 \text { entre los totonacos, y «otros», entre los } \\
\text { Choles. }\end{array}$ & $\begin{array}{l}\text { Parroquias: en } 1609 \text { hay } 42 \text { villas de indios } \\
\text { «tienen sus vice párrocos». En } 1691 \text { hay } 45 \\
\text { parroquias, } 100 \text { Anexas. } \\
\text { En } 1742 \text { en la ciudad una y tres capillas. En el } \\
\text { obispado hay } 45: 10 \text { con secular y } 33 \text { con frai- } \\
\text { les, } 110 \text { capillas. En } 1763 \text { hay } 45 \text { parroquias, y } \\
\text { más «cien pueblos». } \\
\text { Total } 45 .\end{array}$ & $\begin{array}{l}\text { Parroquias: en } 1726 \text { en la villa de Parral 2, di- } \\
\text { rigidas por secular. Los templos con buenos. } \\
\text { En } 1765 \text { hay } 60 \text { y } 74 \text { vice parroquias, provis- } \\
\text { tas de párrocos y vicarios. Total: } 134\end{array}$ \\
\hline $\begin{array}{l}\text { Seminario: en } 1647 \text { se acogen jóvenes po- } \\
\text { bres. En } 1731 \text { hay } 40 \text { estudiantes, se enseña } \\
\text { teología, latinidad, moral e idioma mexicano. }\end{array}$ & $\begin{array}{l}\text { Seminario: en } 1742 \text { registra que «fue funda- } \\
\text { do por el Illmo. Marcos Bravo de la Serna, } \\
\text { hay doce estudiantes». }\end{array}$ & \\
\hline $\begin{array}{l}\text { Conventos: en } 1594 \text { hay siete. En } 1647 \\
\text { además de los anteriores, } 2 \text { carmelitas y dos } \\
\text { mercedarios. } \\
\text { Monasterios: en } 1594 \text { dos monasterios fe- } \\
\text { meninos, de la B. V. María y de Sta. Catalina, } \\
\text { dependen del obispo. }\end{array}$ & $\begin{array}{l}\text { Conventos: en } 1609 \text { están los dominicos, } \\
\text { franciscanos y agustinos. En } 1691 \text { a los frailes } \\
\text { anteriores se agregan los mercedarios. } \\
\text { Monasterios: en } 1609 \text { hay } 1 \text { de S. Domingo, } \\
\text { con muchas monjas. En } 1691 \text { se erigió al } \\
\text { cuidado del obispo, con constituciones, son } \\
\text { pobres y buena edificación espiritual. }\end{array}$ & $\begin{array}{l}\text { Conventos: en } 1726 \text { están los franciscanos, } \\
\text { agustinos, jesuitas, hospitalarios de San Juan } \\
\text { de Dios. }\end{array}$ \\
\hline $\begin{array}{l}\text { Misiones: en } 1731 \text { el obispo señala: de } \\
\text { ellas se ocupan los jesuitas, existe el colegio } \\
\text { Apostólico de Querétaro. }\end{array}$ & $\begin{array}{l}\text { Misiones: en } 1742 \text { se anota más de cien pue- } \\
\text { blos, «he logrado enfrentar la idolatría». }\end{array}$ & $\begin{array}{l}\text { Misiones: en } 1742 \text { está dedicado a las misio- } \\
\text { nes. Se avanza hacia la provincia de Nuevo } \\
\text { México. Los jesuitas y franciscanos tienen } \\
\text { zonas. Entre los pueblos nuevos origina- } \\
\text { rios se registran los apaches. Las distancias } \\
\text { son grandes: el límite norte a } 1900 \mathrm{~km} \text {. de } \\
\text { Durango. }\end{array}$ \\
\hline \multicolumn{3}{|l|}{$\begin{array}{l}\text { Sínodo: en } 1731 \text { el obispo informa que ha } \\
\text { convocado sínodo diocesano. }\end{array}$} \\
\hline $\begin{array}{l}\text { Cofradías: en } 1731 \text { hay confraternidades en } \\
\text { las parroquias y capillas: Virgen de los Dolo- } \\
\text { res, del Rosario, San José. }\end{array}$ & $\begin{array}{l}\text { Cofradías: en } 1742 \text { hay más de } 300 \text { cofradías, } \\
\text { se anota que se han visitado. }\end{array}$ & $\begin{array}{l}\text { Cofradías: en } 1728 \text { se erigen cofradías en las } \\
\text { parroquias. } \\
\text { Santísimo Sacramento. }\end{array}$ \\
\hline Hospitales: en 1594 hay 4. & $\begin{array}{l}\text { Hospitales: en } 1742 \text { uno a cargo de los Hospi- } \\
\text { talarios de San Juan de Dios. }\end{array}$ & \\
\hline $\begin{array}{l}\text { Educación: en } 1594 \text { hay dos colegios: San } \\
\text { Luis, de los dominicos y otro de la Compañía. } \\
\text { En } 1647 \text { se ha erigido otro para pobres. En } \\
1660,3 \text { colegios: E. Santo; S. Ildefonso, uno } \\
\text { de niñas, dirigido por monjas. }\end{array}$ & $\begin{array}{l}\text { Educación: en } 1691 \text { hay un colegio de la Com- } \\
\text { pañía con } 12 \text { estudiantes, enseñan latinidad y } \\
\text { humanidades. }\end{array}$ & \\
\hline $\begin{array}{l}\text { Excepcionales: en } 1731 \text { los oratorianos traba- } \\
\text { jan en catequesis. } \\
\text { Es un desafío «conocer los idiomas de los } \\
\text { naturales: otomí, mixteco, chochas.» En } \\
1731 \text { se propone al Rey: «que se divida en } \\
\text { dos arzobispados, sur y norte, que están las } \\
\text { condiciones para hacerlo». }\end{array}$ & $\begin{array}{l}\text { Excepcionales: en } 1609 \text { indica que «hay voca- } \\
\text { ciones entre indios». } \\
\text { Clero secular: cuando se ausenta por justa } \\
\text { causa "se les da por breve tiempo, con susti- } \\
\text { tuto idóneo». }\end{array}$ & $\begin{array}{l}\text { Excepcionales: las suplicas son de dispensas } \\
\text { matrimoniales. } \\
\text { En } 1642 \text { anotan nombres de pueblos origi- } \\
\text { narios. }\end{array}$ \\
\hline
\end{tabular}

16 Obispos de Puebla: Diego Santiago Romano, 1594; Juan Palafox de Mendoza, 1647; Diego Osorio y Llamas, 1662; Emmanuel Fernández de Santa Cruz, 1681 y 1691; Pedro de Nogales Dávila, 1708; Juan de Lardizabal y Elorza, 1731; Domingo Álvarez de Abreu, 1750.

17 Obispos de Chiapas: Juan Blanes OP, 1609; Francisco Núñez de la Vega OP, 1690; Francisco Núñez, 1699; Jacinto de Olivera Pardo,
1721; José Cubero Ramírez OM, 1742; José Vital de Moctezuma, 1761; José Vita, 1767; Gabriel de Olivares y Benito, 1792.

18 Obispos de Durango: García de Legazpi y Velasco, 1699; Emmanuel de Escalante y Mendoza, 1703; Pedro Tapis, 1716; Pedro Tapis, 1722; Benito Crespo, 1726; Martín de Elizacochea, 1742; Pedro Tamaron y Romeral, 1765; Antonio de Macarulla, 1778. 


\subsection{Contenidos en las Relaciones de Guadalajara y Yucatán}

Estas diócesis están distantes de la metrópolis, empero, alcanzaron maduraciones importantes en la estructura eclesial. La consolidación de Guadalajara se observa en la fundación del seminario en 1676, con las residencias de los oratorianos y de san Carlos Borromeo; mientras que en Yucatán su desarrollo fue lento; prueba de ello, la fundación del seminario data de 1756.

TABLA 4

Contenidos en las Relaciones de Guadalajara y Yucatán

\begin{tabular}{|c|c|}
\hline Diócesis de Guadalajara ${ }^{19}$ & Diócesis de Yucatán ${ }^{20}$ \\
\hline $\begin{array}{l}\text { Cabildo: en } 1734 \text { hay } 12 \text { prebendas, cumplen con las horas canóni- } \\
\text { cas. En } 1757 \text { ha logrado tener el canónigo doctoral. }\end{array}$ & $\begin{array}{l}\text { Cabildo: entre dignidades y canónigos } 12 \text { y cumplen con sus obliga- } \\
\text { ciones litúrgicas. }\end{array}$ \\
\hline $\begin{array}{l}\text { Visita pastoral: en } 1734 \text { se realizó acompañado por misioneros del } \\
\text { colegio de Guadalupe. En } 1754 \text { se realizó la visita durante dos años. }\end{array}$ & $\begin{array}{l}\text { Visita pastoral: en } 1770 \text { indica que realizó la visita durante seis años: } \\
\text { «los peligros están en el mar, en tierra, en los ríos, en los montes, en } \\
\text { los caminos, en los pueblos...». }\end{array}$ \\
\hline $\begin{array}{l}\text { Parroquias: en } 1734 \text { los curas son pocos, buenas costumbres; «las } \\
\text { parroquias de hispanos dirigidas por seculares y las de indios por } \\
\text { regulares». Los oblatos de San Carlos: confesores, doctrineros. }\end{array}$ & $\begin{array}{l}\text { Parroquias: en } 1770 \text { hay } 3 \text { en Mérida, con «buenos templos y ele- } \\
\text { gantes»; los franciscanos sirven } 20 \text { parroquias. } \\
\text { Las iglesias menores alcanzan las } 190 .\end{array}$ \\
\hline $\begin{array}{l}\text { Seminario: en } 1734 \text { registra } 55 \text { estudiantes, de ellos «saldrán los } \\
\text { ministros», dirigido por jesuitas. Al año } 1757 \text { está «floreciente». }\end{array}$ & $\begin{array}{l}\text { Seminario: en } 1770 \text { registra que en él se enseñan las artes y ciencias, } \\
\text { bajo la regla de Trento». }\end{array}$ \\
\hline $\begin{array}{l}\text { Conventos: hay de frailes y jesuitas. Monasterios: en } 1734 \text { uno domi- } \\
\text { nico, dos de Teresa de Jesús, otro de Santa Mónica. } \\
\text { En 1757: uno capuchino en villa Santa María, otro en Zacatecas y } \\
\text { tres en Aguas Calientes. }\end{array}$ & Conventos: en 1615 están en la ciudad los franciscanos. \\
\hline \multicolumn{2}{|l|}{$\begin{array}{l}\text { Misiones: los misioneros se forman en Colegio de Propaganda de } \\
\text { Querétaro, en Nuestra Señora de Guadalupe y de la Compañía de } \\
\text { Jesús. }\end{array}$} \\
\hline & $\begin{array}{l}\text { Sínodo: en } 1770 \text { dice «por muchas dificultades no ha podido cele- } \\
\text { brar sínodo diocesano»; y ha recibido carta del metropolitano, en el } \\
\text { mes de octubre, para celebrar Concilio. }{ }^{21}\end{array}$ \\
\hline Cofradías: hay confraternidades. Santísimo Sacramento. & $\begin{array}{l}\text { Cofradías: en } 1615 \text { anota la cofradía de La Concepción de la Virgen. } \\
\text { En } 1770 \text { anota que son más de } 200 \text {, y «dispersas en las parroquias y } \\
\text { otros lugares menores». }\end{array}$ \\
\hline $\begin{array}{l}\text { Hospitales: en } 1757 \text { hay dos dirigidos por Hospitalarios de S. Juan de } \\
\text { Dios. }\end{array}$ & $\begin{array}{l}\text { Hospitales: en } 1770 \text { hay dos dirigidos por Hospitalarios de S. Juan } \\
\text { Dios. }\end{array}$ \\
\hline \multicolumn{2}{|l|}{ Educación: en 1734 los jesuitas dirigen un colegio niñas. } \\
\hline $\begin{array}{l}\text { Excepcionales: en } 1690 \text { solicita facultades para dispensa matrimo- } \\
\text { niales. } \\
\text { En } 1757 \text { se registra la presencia de los oratorianos y los oblatos San } \\
\text { Carlos. }\end{array}$ & $\begin{array}{l}\text { Excepcionales: en } 1615 \text { se registra las provincias de Yucatán: Mérida, } \\
\text { Conzumel e Izabal; en } 1770 \text { otros lugares: Yucatán, Tabasco, Valla- } \\
\text { dolid. }\end{array}$ \\
\hline
\end{tabular}

19 Obispos de Guadalajara: Leonel de Cervantes y Carvajal, 1632; Juan Ruiz de Colmenero, 1656; Juan de Santiago de León de Garabito, 1690; Nicolás Gómez de Cervantes, 1734; Francisco Martínez de Texada OFM, 1754; Francisco Martínez, 1757; Antonio Alcalde OP, 1781.

20 Obispos de Yucatán: Gonzalo de Salazar OSA, 1614; Juan Cano de Sandoval, 1693; Pedro Reyes de los Ríos, 1703; Juan Gómez de Parada, 1716; Juan de Castonera y Urzúa, 1732; Juan Padilla y Estrada OSA 1759; Antonio Alcalde OP, 1770.

${ }^{21}$ Se refiere al IV Concilio Provincial de 1771 de México. Texto en plataforma digital: Biblioteca Digital Hispánica. Actas del cuarto Concilio Provincial mexicano (Manuscrito). http://Bdh-rd.bne.es

\subsection{Contenidos de las Relaciones de México, Oaxaca y Michoacán}

La diócesis metropolitana cumplió cinco veces con la norma, dos en el s. XVII (1615 y 1694) y tres en el s. XVIII $(1703,1720$ y 1761). Los documentos de 1615,1694 y 1761 abarcan todas las dimensiones eclesiales. 
TABLA 5A

Contenidos en las Relaciones enviadas desde México

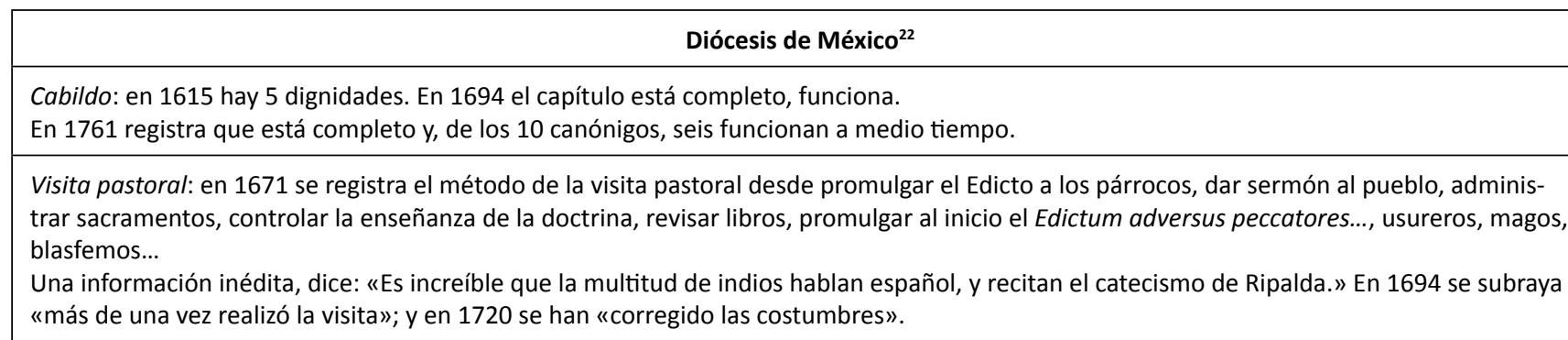

Parroquias: en 1615 la ciudad tiene 5, con cura y buenos templos; doctrinas de indios a cargo de agustinos y franciscanos. En 1694 se agregan que hay 3 en los suburbios; en las villas de indios 6, regidas por los regulares ya nombrados; para los indios que viven en los montes 8 , a cargo de dominicos. La parroquia más distante a $483 \mathrm{~km}$. En 1761 la metrópolis tiene 5 para hispanos, 6 para indios. Total 204 , de ellas 165 al cuidado de seculares, 19 de franciscanos, 12 de dominicos, 8 de agustinos.

Seminario: en 1615 se anotó que es prioridad erigir el seminario. En 1720 el seminario tiene 70 estudiantes y 4 doctores que enseñan. En 1761 se anota que el seminario fue erigido por el arzobispo Francisco Aguilar y Seijas, con 20 estudiantes y los recursos provienen de la mensa episcopal y del aporte de los párrocos; en la visita: «lo ha examinado desde la alimentación a la ciencia que se da».

Conventos: en 1694 están todos los frailes, más carmelitas descalzos y jesuitas.

Monasterios: en 1694 hay 16 monasterios, entre ellos capuchinas y Teresa de Jesús. En 1703 se informa: número excesivo (San Lorenzo, Santa Inés, Santa Teresa en México). En 1761 los monasterios son 23, de los cuales 15 están sujetos al obispo.

Misiones: se registran descripciones como «son idólatras» y «viven en los montes»; en 1694 se anotan dos colegios misioneros, uno jesuita y otro franciscano. Los franciscanos dirigen el de Querétaro. En «los confines las misiones a cargo de dominicos, franciscanos y jesuitas».

Sínodo: en 1615 se observa que «por las grandes distancias es difícil convocar concilio provincial.» En 1761 se repite la observación: «Sínodo no se ha podido tener, los párrocos están distantes, no se pueden alejar de sus iglesias. He usado el Edicto para proponer las providencias».

Cofradías: en 1615 muchas confraternidades, del S. Sacramento en la catedral; del Rosario en los dominicos. En 1694 anota «hay muchas cofradías de distintas devociones».

Hospitales: en 1615 hay 4 hospitales, uno para indios, otro para hispanos, otro en general para "sanos» y otro para enfermos - Hospitalarios: pro infirmis sane mentibus et Hermanos de S. Hipólito pro infirmis amentibus-. En 1720 dos nuevos: Santísima Trinidad y otro de S. Hipólito. En 1761 son 7, dirigidos por Hospitalarios, San Camilo, Bethlemitas.

Hospicios: uno para navegantes, otro para la conversión de los infieles.

Educación: en 1694 anota que el clero «tiene grados menores», los licenciados y doctores trabajan en la universidad. Jesuitas dirigen el colegio San Pedro y San Pablo y otro para indios. Hay un colegio de 24 jóvenes gestionado por una mujer adulta y dos colaboradoras, y al cuidado de la cofradía del S. Sacramento. En 1720 hay 4 colegios: Nuestra Señora de todos los Santos, grados menores; San Raimundo; San Ildefonso, para adolescentes; y, con recursos de la corona se tiene escuelas para españoles.

El desarrollo educacional alcanza todos los niveles en 1761: conventos y monasterios con colegio; de varones 7; de señoritas 4. Universidad una. ${ }^{23}$

Excepcionales:

En 1615 se registran las iglesias sufragáneas y aún se vincula Guatemala.

La ciudad tiene tres ermitas: V. Monserrat, de las monjas de S. Benedicti; y, fuera de la ciudad dos, Sta. María de Guadalupe y a Santa María de los Remedios, con clérigos seculares.

En 1694 se anotan actividades de los oratorianos: predicación, confesión, catecismo, lecciones espirituales, fundaron casa de mujeres mal casadas; casa para mujeres profanas, con tres capellanes, jesuitas y oratoriano; además, en la casa habitan 40 jóvenes huérfanas o pobres. En 1720 se agrega un colegio para jóvenes en la Doctrina Cristiana, costumbre y moral.

Las suplicas en temas matrimoniales: grados prohibidos, bigamia, defecto de nacimiento.

En 1761 anota «fuera de los muros de la ciudad existe Colegiata Santa María Virgen de Guadalupe, patrona de Nueva España, dotada de 10 canónigos y seis porcioneros, uno es el abad, fue erigida en 1748, por Decreto Apostólico».

22 Obispos de México: Juan de la Serna 1615; Francisco de Aguilar y Seixas, 1693; Juan Ortega Montañés, 1703; José Pérez de Lanziego OSB, 1720; Emmanuel Rubio de Salinas, 1761
23 El obispo se refiere a la Universidad Real y Pontificia fundada en 1551. Pérez Puente 2000. Es un texto de referencia obligada sobre la historia de esta universidad. Se abordan todas las dimensiones de la estructura, gestión y formación que ofreció esta institución. 
TABLA 5B

\section{Contenidos en las Relaciones de Oaxaca y Michoacán}

\begin{tabular}{|c|c|}
\hline Diócesis de Oaxaca ${ }^{24}$ & Diócesis de Michoacán²5 \\
\hline $\begin{array}{l}\text { Cabildo: en } 1688 \text { hay } 5 \text { dignidades, } 5 \text { canónigos, } 12 \text { porcioneros y } \\
6 \text { medio porcioneros. }\end{array}$ & $\begin{array}{l}\text { Cabildo: en } 1754 \text { anota que el cabildo tiene } 5 \text { dignidades, } 10 \text { canónigos. } \\
\text { La catedral se inauguró en } 1745 .\end{array}$ \\
\hline $\begin{array}{l}\text { Visita Pastoral: en } 1594 \text { y } 1688 \text { se visitó la diócesis, se ha confir- } \\
\text { mado miles de personas... }\end{array}$ & $\begin{array}{l}\text { Visita Pastoral: en } 1754 \text { se anota que «ha visitado extirpando vicios, } \\
\text { embriagues» }\end{array}$ \\
\hline $\begin{array}{l}\text { Parroquias: en } 1688 \text { hay 101; } 57 \text { regentadas por seculares y } 44 \\
\text { por religiosos. }\end{array}$ & $\begin{array}{l}\text { Parroquias: en } 1754 \text { las parroquias están proveídas con templos sen- } \\
\text { cillos, con curas seculares, bajo los preceptos de Trento y el derecho } \\
\text { patronal. }\end{array}$ \\
\hline \multicolumn{2}{|l|}{$\begin{array}{l}\text { Seminario: en } 1594 \text { no se ha erigido este instituto. En } 1688 \text { se } \\
\text { informa que hay } 28 \text { estudiantes. }\end{array}$} \\
\hline $\begin{array}{l}\text { Conventos: en } 1594 \text { hay dominicos, agustinos, jesuitas, carmelitas } \\
\text { descalzos y franciscanos. } \\
\text { Monasterios: en } 1594 \text { un monasterio de S. Catalina de Siena, al } \\
\text { cuidado de los dominicos. }\end{array}$ & $\begin{array}{l}\text { Conventos: carmelitas, mercedarios, S. Juan de Dios } \\
\text { Monasterios: monjas dominicas, franciscanas, ermitañas de san Agustín. }\end{array}$ \\
\hline Misiones: franciscanos. & $\begin{array}{l}\text { Misiones: se registra que hay una misión en «el límite norte, con los } \\
\text { Chichimecas». }\end{array}$ \\
\hline \multicolumn{2}{|l|}{$\begin{array}{l}\text { Sínodo: en } 1594 \text { anota que aplica el Concilio y el Concilio Mexica- } \\
\text { no. }\end{array}$} \\
\hline \multicolumn{2}{|l|}{$\begin{array}{l}\text { Cofradías: en } 1688 \text { registra que en Semana Santa son muchas las } \\
\text { cofradías penitenciales. }\end{array}$} \\
\hline \multicolumn{2}{|l|}{ Hospitales: en 1594 hay dos hospitales. } \\
\hline \multirow{2}{*}{$\begin{array}{l}\text { Educación: en } 1594 \text { dos colegios, uno jesuita y otro de los domini- } \\
\text { cos, se enseña la teología. } \\
\text { En } 1688 \text { existe el colegio Real de Santa Cruz, aquel de san Bartolo- } \\
\text { mé y uno de Niñas, regentado por una señora adulta. }\end{array}$} & Educación: en 1754 se anota que hay 7 colegios de jesuitas. \\
\hline & $\begin{array}{l}\text { Excepcionales: en } 1616 \text { anota: hay } 7 \text { pueblos, varios «ingenios de oro y } \\
\text { plata». } \\
\text { En } 1754 \text { población compuesta de españoles, etíopes e indios, conocen } \\
\text { las lenguas vernáculas: mazahua, yucateco y otomí. }\end{array}$ \\
\hline
\end{tabular}

\subsection{Análisis de los contenidos en las Relaciones sobre el estado de las diócesis}

Los contenidos de las Relaciones acerca de las estructuras eclesiales, en línea de principios, muestran que ellas están consolidadas a fines del s. XVIII. El análisis es el siguiente:

Cabildo: este órgano es nombrado en todas las Relaciones, la información es muy escueta, número de dignidades y prebendas.

Red parroquial: la parroquia como unidad básica de la iglesia, al individualizarla y caracterizarla se percibe como una red parroquial, lo que evidencia una estructura sólida de una comunidad que posee una columna vertebral, se tiene: México con 204, Guadalajara con 77, Puebla con 119 Michoacán S/I, Chiapas 45 y 100 capillas, Yucatán con 90, Oaxaca con 101 y Durango -última diócesis creada-, con 60 y con 74 vice parroquias. Una red de 725 unidades refleja

24 Obispos de Oaxaca: Bartolomé de Ledezma, 1592; Bartolomé de Benavente y Benavides, 1648; Tomás de Monterosso OP, 1667; Isidro Sarañana, 1688; Miguel Álvarez Abreu, 1772.

25 Obispos de Michoacán: Baltazar de Covarrubias OP, 1617; Martín de Elizacoechea, 1752. una estructura madura. No se incluyen los centros de misión y los anexos.

Seminarios: ${ }^{26}$ si bien las fuentes no ofrecen fechas fundacionales, se infiere por las referencias que éstas fueron tardías. La secuencia fundacional es: Puebla, 1643; Oaxaca, 1673; Guadalajara, 1676; Chiapas, 1678; México, 1697; Durango, 1703; Yucatán, 1756; y, Michoacán, 1776.

Misiones: ${ }^{27}$ en el s. XVIII las zonas de misión ad gentes se detectan al interior de los territorios, en zonas extensas y lejanas de la metrópolis: Durango, Michoacán, Chiapas.

Se destacan las misiones de dominicos, franciscanos y jesuitas; no obstante, se observa que la mayor extensión fue la franciscana, quienes cubrieron todas las diócesis y dirigieron los colegios de Propaganda. Todos los textos hacen referencia a los franciscanos, quienes habían llegado, tempra-

26 Los años fundacionales de los seminarios son los propuestos en el trabajo de Vergara 2005.

27 Borges 1992. El autor ofrece una serie de nóminas del proceso de instalación y desarrollo de la acción misionera en todo el continente, incluye Filipinas. Además de precisar las fundaciones de los colegios de Misiones. La información de Borges es congruente con aquella que se registró en las Relaciones. 
namente, hacia 1525 e inician la actividad misionera desde Michoacán. ${ }^{28}$

Conventos de regulares: los clásicos frailes mendicantes están extendidos por las diócesis, a los que se debe agregar los jesuitas. Todos fundaron colegios, dirigen los seminarios, misiones y atienden los curatos en los primeros cien años.

Nuevas comunidades religiosas: las Relaciones ofrecen información inédita acerca de los clérigos Oratorianos, San Camilo, oblatos de San Carlos y Betlemitas, en el sentido que registran datos sobre los trabajos que asumían y de los espacios geográficos donde habitaban.

Monasterios femeninos: estas expresiones religiosas tuvieron un desarrollo importante en todo el continente. Al comparar las Relaciones de las metrópolis de México y Lima la diferencia radica en que los arzobispos limeños registraron información estadística, ${ }^{29}$ mientras que los mexicanos se restringen al número de monasterios.

Iglesia Colegiata: una, es el santuario de la Virgen de Guadalupe, con cabildo y abad.

\section{CONCLUSIONES DEL ESTUDIO}

El desarrollo de las conclusiones tendrá dos hilos orientadores, esto son, las dimensiones eclesiales que individualizan tanto los cimientos como el carácter de la comunidad; y, las estructuras institucionales que individualizan aquellas que construyeron la institucionalidad eclesial.

Luego, desde la teología política, los hilos van articulando el modelo de iglesia que se instaló en América Latina, esto es, la extensión de la sociedad política del medioevo, la cual encuentra en el concepto dominium de ecclesia la síntesis de la unidad entre la esfera civil-eclesiástica, política-religiosa, temporal-sobrenatural, el cual se remonta a la concepción ecclesiam et imperium esse unum et ídem; en este caso, el proceso evangelizador fue mediatizado a través de las reformas conciliares y las Leyes patronales.

De este modo, las dimensiones eclesiales y las estructuras institucionales leídas desde la teología política subyacente -dominium de ecclesia y la doctrina y reforma del Concilium Tridentinum-, harán emerger el estado de la iglesia de la provincia mexicana.

\subsection{El modelo del Concilio de las dimensiones eclesiales}

El obispo como órgano central de la pastoral de Trento

Los obispos al citar las normas conciliares y patronales evidencia la convergencia de ambos códigos, se refuerzan las lógicas ordenadoras del ministerio episcopal, el que se concretiza en deberes, como: realizar la visita pastoral, predicar, administrar los sacramentos, promover la catequesis, fundar el seminario, instalar el cabildo. De estos encargos, se han elegido ejes claves de la pastoral tridentina, esto es: la visita pastoral, como el instrumento de reforma permanente; y, la administración de los sacramentos y la catequesis, como medios para la salvación de las almas y conserva-

28 McCloskey 1955. Esta obra clásica describe en el capítulo primero la expansión misionera franciscana: Michoacán 1525, Guadalajara 1541, Zacatecas 1546, Durango 1550.

29 Camus Ibacache 2019. ción de la doctrina, las que serán gestionadas por la cofradía del Santísimo Sacramento y de la Doctrina Cristiana.

Respecto a la práctica de visita pastoral se constata que está referida en todas las Relaciones. La descripción más completa de ella, se registra en la Relación del arzobispo, del año 1671. El obispo anotó los pasos principales de la auditoría: decretó el Edicto con el cual anunció la visita a los párrocos; en cada parroquia se inició con el sermón al pueblo; administró los sacramentos; controló si se enseñaba la doctrina cristiana; revisó los Libros; promulgó en la primera iglesia visitada el Edictum adversus peccatores publici indixi, contra usureros, magos, sortilegios, blasfemos...; y, controló la comunión pascual. ${ }^{30}$ Un registro inédito: «Es increíble que la multitud de indios hablan español, y recitan el catecismo del Padre Ripalda».

Luego, en la visita de 1694, después de indicar que los párrocos tienen los Libros parroquiales, anota que en «todos los curatos se tiene la doctrina del Cardenal Roberto Belarmino, impreso en España. ${ }^{31}$ En las Relaciones de las Provincias eclesiásticas de Guatemala y de Lima, no hay referencias a textos de catequesis. ${ }^{32}$

La valoración de las fuentes históricas de la visita pastoral, se subraya que éstas siguen siendo una referencia archivística de datos, sobre el desarrollo de la estructura parroquial; su distribución espacial, capillas y anexos e, individualizar las regentadas por el clero secular o regular y los componentes sociales. ${ }^{33}$

Las cofradías del Santísimo Sacramento y de la Doctrina Cristiana son instituciones surgidas del Concilio, como prioridades pastorales; las que se reforzaron en 1607 con Clemente VIII al mandar implementarlas en todas las parroquias. ${ }^{34}$ En el lenguaje de la época la pastoral comunitaria se organizaba a través de cofradías, hoy este término está en desuso, es una observación útil, para no confundirla con aquellas cofradías devocionales.

A pesar de la prioridad que estas dos cofradías tenían en la pastoral, las Relaciones ofrecen escasos datos. En el año de 1605 el arzobispo y los obispos de Durango en 1722 y de Guadalajara en 1734 hacen referencia a la del S. Sacramento; y, aquella de la Doctrina Cristiana no se registran referencias. Sobre el silencio de este instituto se propone, que en México ella fue suplida por los catecismos del concilio provincial de 1585; por el desarrollo de la Escuela de Cristo de los oratorianos y, por el catecismo de Ripalda. El arzobispo en 1694 anota: "existe el Oratorio de Felipe Neri, dan asistencia a la confesión, predicación, catecismo, lecciones

30 Respecto a la promulgación de un Edictum adversus..., se trata de un protocolo antiguo que se instaló después de Trento, en contexto de «reformas». Un estudio particular, con aplicación general en los dominios de España, es el de: Marín López 1997. El autor ofrece detalles del origen y el sentido del texto, la fuente primaria es el Edicto del prelado Pedro Guerrero.

31 El Catecismo de J. Ripalda S.J., data de fines del s. XVI. Duque Alcaide 2008. Respecto al texto del cardenal Belarmino, es probable que se refiera Christianae doctrinae explicatio.

32 Camus Ibacache 2018; 2019.

33 García Hourcade e Yrigoyen López 2006.

34 Clemente VIII. Constitución Quaecumque (7 diciembre 1607), señala: «en una misma ciudad o pueblo no puede haber dos cofradías del mismo instituto [...]; esta prohibición no comprende a las cofradías del Smo., y de la Doctrina Cristiana, que pueden erigirse en todas las iglesias parroquias». Cf. Ferraris Lucci 1845. Voz «Confraternitas». Prompta Bibliotheca. T. II, art. I, $\mathrm{n}^{\circ} 45$. 
espirituales"; y, anota el uso del catecismo del cardenal Belarmino. El desarrollo de esta cofradía, como se presentan en este estudio, se convierte en prioridad en América Latina cuando fue impulsada por el Concilio Plenario de A. Latina, celebrado en Roma, en 1899. ${ }^{35}$

\section{- Los colegios misioneros}

Si bien estas fuentes no registran datos cuantitativos, hay referencias de su desarrollo. Los arzobispos nombran los colegios de Propaganda: de la Santa Cruz de Querétaro (1683), el de Nuestra Señora de Guadalupe de Zacatecas (1704), de San Fernando y de Pachuca de México (1734), a cargo de frailes franciscanos, también aluden a los colegios jesuitas. Los obispos de Guadalajara y Puebla anotan que los misioneros se forman en Querétaro y en Zacatecas y otros, con los jesuitas.

De otras anotaciones en la Relaciones se deducen algunos contenidos en la formación del misionero: la multiplicidad de etnias sugiere temas socio antropológico; que "hay 23 idiomas» en la diócesis, se infieren los desafíos catequéticos, litúrgicos; la reducción de los indígenas a pueblos, invita a pensar en escuelas, en trabajo técnico.

- El desarrollo del monacato femenino ${ }^{36}$

Esta expresión religiosa es extensa en la provincia e intensa en la metrópolis. Las fundaciones se inspiran en distintas espiritualidades, se erigen bajo dependencia canónica de una orden religiosa o del obispo. La Relación de 1761 registra 23 monasterios, de los cuales 15 bajo la dependencia del obispo. ${ }^{37}$

Estas fuentes permiten seguir el desarrollo monacal en términos muy genéricos: la metropolitana en 1615 tenía 14 claustros y en 1761 se incrementaron a 23; en Yucatán al año 1770 sólo había 1 monasterio; en Chiapas, 1 monasterio, bajo la tutela del obispo, en 1692; en Guadalajara en 1734 con 4 monasterios; en Michoacán se fundaron 4 monasterios. Total 34 claustros.

Las primeras expresiones monásticas femeninas fueron las de Catalina de Siena, tutelada por los dominicos. La existencia de los monasterios sieneses fueron registrados en las Relaciones de Puebla y de Oaxaca, del año 1594. Estudios recientes muestran que se fundaron también en Guadalajara, 1588; y, en Michoacán, $1595 .^{38}$ Las Relaciones registran otros monasterios: Capuchinas, Teresa de Jesús, San Lorenzo, Santa Inés, Virgen de la Concepción, Clarisas, Santa Rosa, Carmelitas, Encarnación, Santa Mónica.

\section{- Pastoral de los institutos religiosos nuevos}

En esta sección se subraya la presencia en la provincia eclesiástica de México de los Oratorianos. En esta línea, se subraya la influencia en la formación de personas: el obispo

35 Concilio Plenario de América Latina, Roma 1899, Título X, De la doctrina Cristiana. Tipis Vaticanis 1900.

36 La información en las Relaciones respecto a los monasterios femeninos es limitada, la historiografía ha realizado aportes sólidos sobre el monacato en la provincia mexicana, cf. Martínez Cuesta 1995 donde se ofrece información estadística, año de fundación y población religiosa entre otras.

37 El arzobispo de México en 1761 registra los monasterios bajo la dependencia del obispo: "BMV, de la Concepción; BMV, Reina de Cielo; De Jesús y María; S. Jerónimo; San Lorenzo; Santa Inés; San José de Gracia; San Bernardo; Santa Teresa antigua y nueva; Capuchinas; Santa Brígida; BMV de la Columna».

38 Zarate Quevedo 2016. de Puebla en 1731 indica "ellos tienen 10 Escuelas»; aquel de México en 1720 señala que tienen colegio para jóvenes en la doctrina cristiana, costumbre y moral, atienden una casa de mujeres. En 1757 se encuentran en Guadalajara los oratorianos y los oblatos.

La influencia de los oratorianos la ejercen a través de clero propio y de los laicos que se enrolan en sus obras. Por ejemplo, entre 1659-1714: varios oratorianos fueron vicarios generales, otros miembros del tribunal de la Inquisición, otros profesores de la Universidad; por otro lado, están los benefactores de las obras sociales que fundaron casas de recogidas, hospitales. Sin descuidar la formación espiritual, la predicación y obras de asistenciales. ${ }^{39}$

\subsection{El desarrollo eclesial desde las estructuras institucionales}

Estas conclusiones individualizarán las principales estructuras que explican el desarrollo consolidado de la provincia eclesiástica, a fines del s. XVIII. La investigación propone cuatro pilares, los que se argumentaran a partir de la información registrada en las fuentes y apoyados en la historiografía actual.

Las preguntas principales que se decantaron a lo largo de la investigación, son: ¿Qué factores impulsaron el desarrollo autónomo de las diócesis lejanas a la metrópolis? ¿Cuál es el peso del sistema educativo en el desarrollo eclesial y social? ¿Cuál fue el rol del cabildo catedralicio, mínimamente registrado, tanto en la estructura eclesial como en la organización sociopolítica? y, ¿Cómo se generó la recepción de la Madre de Dios en la advocación de Guadalupe como la patrona de la provincia eclesiástica? Las respuestas a estas preguntas constituyen el núcleo conclusivo del estudio.

- La unicidad eclesial y la diversidad territorial: la autonomía

La unicidad eclesial es una de las notas distintivas de la Iglesia católica que madura a través de los siglos. Esta nota entró en tensión en Nueva España, al tener que acompañar la política civil de acelerada expansión territorial administrativa; ante ello, el planeamiento misional respondió a esa estrategia, adoptando las políticas y mecanismos pastorales, los que encontraron un especial impulso, con la creación de la Congregación Propaganda Fide en 1622; la cual desarrolló y fortaleció la consolidación de la iglesia en las nuevas zonas de misión, con acciones concretas para un desarrollo más autónomo de la expansión misional, un ejemplo de ello fue la fundación de colegios misioneros. ${ }^{40}$ Hay que relevar a primer nivel, que el éxito de las misiones fue favorecida por la articulación de la administración eclesial y el derecho patronal.

En este escenario se comprende la política de movilidad episcopal y la procedencia secular del obispo, a fin de fortalecer la estabilidad y la colegialidad episcopal con el desa-

39 Reed 2018. Cf. Bazarte Martínez y Cruz Rangel 2009. Ambos estudios abordan con fuentes primarias la acción socio religiosa y política de la Venerable Unión de los oratorianos y las Escuelas de Cristo de la Congregación de los Oratorianos.

40 America Pontificia III. Metzler 1997. El autor ofrece una síntesis de la documentación del volumen III, en el cual subraya la incidencia de la S. Sede en la actividad misionera en América. 
rrollo local autónomo. De la tabla 1, de la relación obispos regulares o seculares, se deducen aspectos de estabilidad.

- Las diócesis de México, Puebla y Michoacán en la relación obispo regular y obispo secular $(r / s)$, fue temprana a favor de un episcopado secular.

En el periodo se observa que en la primera diócesis fue $5 / 18$, la segunda $3 / 19$ y la tercera $8 / 19$. Al profundizar, se observan diferencias entre las diócesis: México con más obispos seculares y alta rotación en el s. XVII, lo que se tradujo en inestabilidad; esta tendencia cambió en el s. XVIII, con gobiernos prolongados; Puebla muestra un proceso inverso, fueron más los obispos seculares en el s. XVIII e inestabilidad pastoral, el efecto se contuvo con otras estructuras, como fue la movilidad de miembros de los cabildos eclesiásticos entre diócesis y la incorporación de clérigos de comunidades nuevas, en especial, los oratorianos y los oblatos de san Carlos. ${ }^{41}$ La tercera diócesis atravesó el s. XVII con una rotación alta, la que se profundizó en el s. XVIII, el cabildo asumió sus roles con eficiencia.

- Los prelados de Chiapas y Yucatán proceden del clero religioso

El factor de zonas extremas - $960 \mathrm{~km}$ de la metropolitana- generó dos efectos: estas diócesis permanecieron como espacios de misión permanente; y, desarrollaron autonomía en la resolución de problemas. La locación de Chiapas así lo prueba, la cual a pesar del cambio de su cualidad de sufragánea de México por Guatemala, no afectó su desarrollo. Es evidente que la estabilidad del ministerio episcopal entre 1682 y 1766 -84 años - y, prelados criollos desde 1670 fueron factores de consolidación. Yucatán con un equilibrio entre prelados religiosos y seculares logró consolidar una red de 90 parroquias, fundar el seminario y mostrar una práctica de visita ad limina óptima en el s. XVIII.

- El cabildo como órgano articulador de poder político en el desarrollo de la iglesia

La información en las Relaciones sobre el cabildo es escueta, se limitan a señalar el número de miembros, cuántos están provistos, algún detalle del funcionamiento. Esta estructura colegiada consolidada con normas y funciones desde el s. XI, fue sujeto de las reformas del Concilio, a fin de corregir aspectos de su funcionamiento. Las reformas se orientaron a transparentar sus actividades, regular la acumulación de beneficios, asegurar la residencia de sus miembros, fortalecer el vínculo con el obispo, entre otras. Este órgano reformado fue el que se implantó en América Latina.

La recepción de las reformas conciliares se tradujeron a las Leyes de Indias, en el: Libro I, Título VI., Leyes I-VIII «referidas al patronazgo real de las Indias, acerca a como se proveen las dignidades y prebendas por presentación al Rey a sus prelados»; Título $\mathrm{XI}$; «referidas a las dignidades y prebendas de las iglesias metropolitanas y catedrales de las Indias", Ley I acerca de la residencia, Ley VIII sobre que las autoridades controlen e informen de las ausencias, Ley $X$ evitar daños en sede vacante; $y$, Título VII referidos a los arzobispos, obispos y visitadores, acerca de la visita en sede vacante.

41 Castillo Flores 2016. El autor demuestra que los miembros del cabildo transitaban entre diócesis, afirma: "estos cinco cabildos conformaron lo que consideramos una red eclesiástica de movilidad, caracterizada por la circulación intercatedrales de sus miembros».
Los encargos del cabildo como «corporación de eclesiásticos de la catedral», además de los litúrgicos y en la participación al coro y el altar; dan consejo al obispo en los negocios de importancia, en el gobierno interno de la catedral y de la diócesis. Por tanto, sus competencias eran legislativas y ejecutivas; y, asumir la administración de la diócesis en periodo de vacancia, nombrando un vicario capitular, en el término de ocho días.

Los cabildos de estas iglesias han sido de interés de investigación en las últimas décadas, sobresalen los aportes liderados por Leticia Pérez Puente y José Castillo Flores. ${ }^{42}$ Dos estudios pertinentes a este trabajo son los de José Castillo Flores y de Oscar Mazín. ${ }^{43}$

El primero profundiza el rol político, económico, social y religioso del cabildo, subraya la movilidad y las redes eclesiásticas del cuerpo capitular; analiza los vínculos entre los cabildos de México-Puebla-Michoacán y Oaxaca, relevando la movilidad de los capitulares entre diócesis; el modelo el autor lo extrapola a las diócesis de Chiapas-Yucatán y Guatemala. El autor concluye:

a. El órgano capitular fue la instancia privilegiada para que el clero criollo asumiera un rol importante en la conducción de las iglesias: movilidad hacia el episcopado, acceso a Vicarios capitulares en sede vacante, incorporación a los seminarios, gestores de la «fábrica de la catedral».

b. En asuntos públicos ejercen influencia directa en la conducción de la universidad.

c. Sus miembros sostienen obras de beneficencias, promueven la educación primaria y secundaria.

En síntesis, recurriendo a los estudios de Rodolfo Aguirre Salvador, se sostiene que las funciones del cabildo fortalecieron el desarrollo de la comunidad eclesial y de la sociedad, la que fue apoyada por la red de parentesco y vínculos económicos con la estructura administrativa. ${ }^{44}$

El segundo investigador ofrece otra perspectiva de análisis, cuyo eje es la participación del cuerpo capitular en la construcción de las «repúblicas urbanas» en Nueva España, en los siglos XVII-XVIII, evidenciando la inserción capitular en tres diócesis conectadas: México-Michoacán-Puebla.

El investigador demuestra como el cabildo impulsó proyectos eclesiales y públicos, entre algunos:

a. En Michoacán acompañan obras educativas: colegio Santa Rosa, de San Francisco Javier y el seminario. Además de la participación en la gestión económica de hospitales, hospicios, abastos.

b. En Valladolid de Michoacán participan en la organización social y urbana, la cual se aprecia en el ordenamiento arquitectónico de la ciudad, con la centralidad del templo y obras constructivas mayores en su entorno.

c. En México gestionan la construcción del santuario de Santa María de Guadalupe.

42 Pérez Puente y Castillo Flores 2016.

43 Castillo Flores 2016; Mazín 2016.

44 Aguirre Salvador 2016: propone al capítulo catedral como el órgano de movilidad social, a través del seguimiento acucioso de la biografía de un clérigo mexicano. 
d. En el caso de la diócesis de Puebla es suficiente citar al investigador al respecto: "Me refiero a la serie de condiciones regulares y duraderas mediante las cuales cada catedral participó de manera activa en la organización de numerosos grupos sociales y entidades corporativas. Cuatro son las áreas o campos principales de actividad por estudiar: el culto, la beneficencia, la enseñanza y el préstamo de caudales. Por sus contenidos y criterios organizativos, los repositorios documentales que hacen de su entrecruzamiento una fuente de sorpresas para iluminar dicha proyección son el archivo capitular de cada catedral y el de protocolos notariales.»
- El desarrollo de un sistema educacional

La información acerca de esta variable de desarrollo es genérica en las Relaciones, pero suficiente para describir la obra educativa, pues se encuentran registros de la mayoría de las diócesis. En las tablas de contenidos se anotaron tipos de colegios, responsables institucionales - religiosas o religiosos-, grupos de destinatarios.

Las congregaciones religiosas asumieron encargos educativos desde el nivel básico al superior. La red educativa eclesial y la instalada por la corona se constituyeron en un soporte indiscutible del desarrollo. La tabla siguiente recapitula las obras educativas.

TABLA 6

Instituciones educativas registradas en las Relaciones

\begin{tabular}{|c|c|c|c|}
\hline Diócesis & Seminario ${ }^{45}$ & Colegios & Universidades \\
\hline Puebla & 1643 & $\begin{array}{l}\text { En 1594: el colegio San Luis, de los dominicos y otro de jesuitas. } \\
\text { En 1647: un colegio para pobres. } \\
\text { En } 1660 \text { tres colegios: E. Santo y de San Ildefonso, otro de niñas, dirigi- } \\
\text { do por monjas. }\end{array}$ & \\
\hline México & 1697 & $\begin{array}{l}\text { Hacia } 1694 \text { colegio Máximo San Pedro y San Pablo, colegio para indios. } \\
\text { Colegio para niñas, dirigida por seglar adulta. }\end{array}$ & $\begin{array}{l}\text { Real y Pontificia } \\
\text { Universidad, se fundó } \\
\text { en } 1551 .\end{array}$ \\
\hline Michoacán & 1776 & En 1754 se registra 7 colegios de jesuitas. & \\
\hline Guadalajara & 1696 & Colegio jesuitas para niñas. & \\
\hline Yucatán & 1756 & & \\
\hline Oaxaca & 1673 & $\begin{array}{l}\text { En 1594: dos colegios, uno jesuita y otro de los frailes dominicos } \\
\text { En 1688: colegio Real de Santa Cruz, aquel de san Bartolomé y colegio } \\
\text { de niñas }\end{array}$ & \\
\hline Chiapas & 1678 & En 1691: colegio de la Compañía. & \\
\hline Durango & 1705 & En 1765: colegio de la Compañía & \\
\hline
\end{tabular}

Aspectos a subrayar: el rol que las órdenes religiosas masculinas tuvieron en la fundación de instituciones educaciones, llamadas colegios; la corona legisló para fundar instituciones educacionales a cargo al erario real; en educación superior se instaló una política mixta, la universidad fue definida de Real y Pontificia y Propaganda Fide legitimó los grados académicos de los colegios conventuales; los seglares asumieron roles en la construcción y dirección de colegios; y, los cenobios femeninos aportaron en la formación de las jóvenes.

En este mismo sentido la influencia en la formación de capital cultural en las comunidades locales fue decisoria la participación de las instituciones eclesiales, v. g., los franciscanos en el nivel primario y los jesuitas en el secundario. El historiador eclesial, Mariano Cuevas indica que en el s. XVII había 27 colegios secundarios en Nueva España, la mayoría a cargo de los jesuitas. ${ }^{46}$ La complejidad lograda por el sistema educativo superior, a mediados del s. XVIII, es de tal densidad, que favoreció las capacidades profesionales de la sociedad, en lo general; y, al segmento criollo, en lo

45 En las Relaciones se registran referencias al seminario, en algunos casos, sólo se indica el número de estudiantes. Para la data de la fundación cf. Vergara 2005.

46 Cuevas 1924. particular, le ofreció el acceso a una formación superior sin la necesidad de trasladarse a España. ${ }^{47}$ Un rol importante lo tuvo el cabildo en el desarrollo de la universidad y de los seminarios, tanto en asuntos de gestión de recursos como formando parte de los cuerpos colegiados y docentes.

Otro contenido que surge es la participación de seglares en el desarrollo de las obras educativas de la iglesia, v.g., la cofradía de S. Sacramento era responsable del colegio para Niñas en México, y que una «mujer adulta» lo dirige. ¿Es el mismo modelo de los otros colegios para Niñas en Oaxaca, Puebla o Guadalajara? Los textos discriminan la institución a cargo del colegio, pero nada más. Un texto indica: un colegio está a cargo de los jesuitas y otro de monjas, pero ¿cuál es la fuente de sustentabilidad económica? ¿Cuántos colegios reciben aporte fiscal? En cualquier de estos escenarios las fuentes ofrecen aspectos genéricos de la complejidad del sistema educativo; lo que indica la participación de otras instituciones eclesiales.

47 Marsiske 2006, señala: «Por otra parte, el establecimiento de tres nuevas instituciones de educación superior por el régimen Borbón en la Nueva España, amenazaba con destituir a la Universidad de sus privilegios y canonjías como rectora de la educación superior. Estas instituciones fueron: la Real Academia de Bellas Artes de San Carlos, fundada en 1784; el Jardín Botánico, inaugurado en 1788, y el Real Seminario de Minas, establecido hacia 1787». 
- La espiritualidad mariana: una cuestión estructural

Al indagar sobre las figuras patronales de las dos primeras diócesis, el contenido de la advocación mariana marca las dos primeras fundaciones: la diócesis primada de Puebla o Tlaxcala fundada en 1525, tiene de patrona la Inmaculada; y, en el año 1530, al crearse la diócesis de México, se la encomienda a la Asunción.

La historia de la devoción mariana guadalupana, sólo con las fuentes de visita ad limina, es posible detectarlo ya en la Relación del arzobispo De la Serna, del año 1615, él registró tres ermitas dedicadas a: la Virgen de Monserrat, a cargo de las monjas de S. Benedicti; fuera de la ciudad, una dedicada a la Virgen de Guadalupe y, la otra a la Virgen de los Remedios, con clérigos seculares. En otras Relaciones al registrar los colegios misioneros de Propaganda Fide, se anota el colegio de Nuestra Señora de Guadalupe de Zacatecas, fundado en 1704. Los obispos de Guadalajara registran que los misioneros se forman en los colegios de Querétaro y de Nuestra señora de Guadalupe de Zacatecas.

La referencia más clara en lenguaje canónico se conserva en la Relación del arzobispo Rubio de Salinas, del año 1771, anotó "fuera de los muros de la ciudad existe la Colegiata Santa María Virgen de Guadalupe, patrona de Nueva España, dotada de 10 canónigos y seis porcioneros, uno es el abad, fue erigida en 1748, por Decreto Apostólico.»

Es en este escenario de la historia de la mariología, que las preguntas ¿cómo la devoción guadalupana llegó a ser parte del ethos de la comunidad católica mexicana, y cuál sería el aporte a la tradición mariana occidental? ¿Cómo se podría explicar este ethos mariano?

La comunidad católica española, al tiempo de la evangelización de América Latina, estaba en curso un culto a María inédito al resto de las comunidades europeas. Este surco histórico venía madurando desde el tiempo del Alfonso X el Sabio (1252-1284), a quien se atribuye la composición de las Cánticas a María; este proceso cultual derivó en el misterio de la Concepción de María. He aquí la novedad, la comunidad española se posicionó como «lugar teológico» tanto del debate teológico como de la propagación de la devoción. Las comunidades europeas de la época reconocieron el sitial de España en esta historia. En síntesis, en España maduró la recepción definitiva del misterio de la Inmaculada ${ }^{48}$; esta doctrina y devoción fue la proyectada en estas iglesias.

El caso de la provincia mexicana fue un plus en la historia de la recepción de estas advocaciones marianas: las diócesis que tuvieron como patrona la Virgen María, bajo el título de la Asunción son México, Guadalajara, Yucatán y de la Inmaculada son Puebla y Michoacán, todas con la aprobación canónica, pues la referencia está en la bula de creación de la diócesis.

Esta tendencia mariológica se explicitó en la recepción de la devoción a María, con el nombre de Guadalupe, pero bajo el título de Madre de Dios. Este trabajo propone ciertos hitos teológicos pastorales que se dieron en esta dirección:

a. Desde los inicios la dinámica devocional a María de Guadalupe fue asociada al título de Madre de Dios,

48 Ruiz-Gálvez Priego 2008. El estudio precisa el desarrollo histórico del dogma desde el s. XI y el rol protagónico de la cultura española en su consolidación. asunto que se evidencia al ser declarada patrona de la ciudad de México, en 1637.

b. Cien años después, María de Guadalupe, en 1747 fue declarada patrona de la provincia de Nueva España, siempre Madre de Dios.

c. En IV Concilio Provincial mexicano de 1771, si bien no fue aprobado, se refrendaron dos tradiciones: la tradición ya madurada en la comunidad española, al establecer el Libro I, Tít. único, del Juramento, que: «guárdese la costumbre de añadir el juramento de defender la Inmaculada Concepción María Santísima»; luego, en el Libro II, Tít. VIII, en la nómina de feriados con obligación de misa, establece: "La Concepción de Nuestra Señora, protectora general de todos los dominios católicos, el 8 diciembre y Nuestra señora de Guadalupe, patrona de este reino... el 12 diciembre».

El misterio de la Inmaculada alcanzó su máxima en 1771: «protectora general de todos los dominios de nuestro Rey Católico... y... Nuestra Señora de Guadalupe». ${ }^{49}$ Es posible elaborar un silogismo: la Inmaculada es patrona de todos los dominios, Guadalupe es patrona de Nueva España, que es también dominio español ¿Se podría deducir que Guadalupe es también expresión de la Inmaculada? No era necesario porque Nuestra Señora... hace referencia al primer dogma mariano fijado en el Concilio de Éfeso 431: María, Madre de Dios.

En este contexto, la recepción de ambas devociones en toda América Latina es inédita y se constituyó en sustrato importante, para la declaración de ambos dogmas, la Inmaculada, en 1854 y la Asunción, en 1950. ${ }^{50}$

Este aporte a la cultura cristiana desde América Latina no ha sido ponderado desde una perspectiva teológica, esto es, discriminar como estas dos tradiciones tuvieron una recepción original en este continente y aquel de Guadalupe explicita el primer dogma y fuente de los otros. No es posible reducir a procesos culturales devocionales el carácter mariano de estas comunidades; ni tampoco acotar la devoción mariana en clave de contrarreforma tridentina.

En este estudio, se ha probado que la evangelización de América Latina se hizo con las reformas conciliares, pero la recepción de esas fue en clave misionera. Otras miradas, que ciertamente son un aporte valioso, racional y respetable, corren el riesgo de encapsularse en una visión socio antropológico, que en cierta forma reduce la historia del dogma. El historiador, Rubén Vargas Ugarte y la investigadora Alicia Mayer, representan estas tendencias. Esta observación no desmerece los aportes significativos de ambos, v. g. la contribución de Mayer es extraordinaria, en el sentido de fijar ese desarrollo críticamente. ${ }^{51}$

49 Concilio Provincial de México, 1771. Libro I, Título Único: De la Profesión de la Fe (edición de 1898); Libro II, título 8. De los días feriados, se indica el 8 diciembre: la Concepción de Nra. Sra., Patrona de todos nuestros Dominios. Cf. Biblioteca Digital Hispánica: (Manuscrito) http://Bdh-rd.bne.es.

50 Pío IX, Epístola apostólica de Pío IX, Ineffabilis Deus (8 de diciembre de 1854); Pío XII, Constitución apostólica Minificentissimus Deus (1 de noviembre de 1950).

51 Vargas Ugarte 1947, 836. Es un estudio que analiza cómo aparecieron los cultos marianos en toda América Latina; y Mayer 2002. 
La conjunción de las cuatro dimensiones eclesiales, esto es, el obispo de perfil trentino, los colegios misioneros, el monacato femenino y los oratorianos con una innovadora pastoral con las cuatro estructuras eclesiales, como son la unicidad eclesial y civil, el cabildo catedralicio como órgano social y político, el desarrollo de un sistema educativo complejo y, todo ello, articulado por una espiritualidad mariana se constituyen en una expresión inédita de la iglesia católica.

\section{FUENTES}

America Pontificia III. Documenti Pontifici nell'Arhivio Segreto Vaticanoriguardanti I'Evangelizzazione dell'America: 1592-1644. Collectanea Archivi Vativani. 38. Citta del Vaticano 1995. 863 pp.

Concilio Plenario de América Latina, Roma 1899. Typis Vaticanis 1900.

Concilio Provincial de México, 1771. Biblioteca Digital Hispánica. Actas del cuarto Concilio Provincial mexicano (Manuscrito). http://Bdhrd.bne.es

Hierarquia Católica Medii et Recentioris Aevi, vol. III 1503-1592, Patavii 1960² vol. IV 1592-1667, Patavii 1947²; vol V, 1667-1730, Patavii 1952 y vol. VI 1730-1799, Patavii 1958

Lucii Ferraris. 1845. Prompta Bibliotheca. T. II, art. I, n 45.

Pío IX, Epístola apostólica de Pío IX, Ineffabilis Deus (8 de diciembre de 1854); Pío XII, Constitución apostólica Minificentissimus Deus (1 de noviembre de 1950).

Sixto V, la Constitución Apostólica, Romanus pontifex (20 diciembre 1585).

\section{BIBLIOGRAFÍA}

Aguirre Salvador, Rodolfo. 2016. "De las aulas al Cabildo Eclesiástico. Familiares, amigos y patrones en el arzobispado de México, 16801730». Revista Estudios Históricos Tzintzun 47: 75-114.

Bazarte Martínez, Alicia y José Antonio Cruz Rangel. 2009. «Las Santas Escuelas de Cristo en la segunda mitad del siglo XVIII en la ciudad de México». Fuentes Humanistas 21(38): 179-199.

Berthe Jean-Pierre. 2002. "Les rapports des visites ad limina des évêques de Nouvelle-Espagne aux xvi ${ }^{\mathrm{e}}$ et xviie siècles». En Les Chemins de Rome. Les ad limina à l'époque moderne dans l'Europe méridionale et le monde hispano-américain (xvie-xix siècle), ed. Philippe Boutry et Bernard Vincent, 197-211. Roma: Ecole Francaise de Rome.

Borges, Pedro. 1992. «La expansión misional». En Historia de la Iglesia en Iberoamérica y Filipinas, ed. Pedro Borges, 471-494. Madrid: la editorial católica.

Brading David. 1994. Michoacán, una iglesia Asediada 1749-1810. México: Editorial Fondo Cultura Económica.

Camus Ibacache, Misael. 2018. "La práctica de la Visita ad limina Apostolorum. Provincias eclesiásticas de Guatemala y de Santa Fe: 1600-1800». Hispania Sacra LXX, 142: 613-628. https://doi. org/10.3989/hs.2018.042

Camus Ibacache, Misael. 2019. «Desarrollo de la provincia eclesiástica de Lima 1599-1800, focalizado en la relación metrópolis y diócesis periféricas, en las Relaciones de visita ad limina Apostolorum". Hispania Sacra LXXI, 144: 503-320. https://doi.org/10.3989/ hs.2019.036

Cárcel Ortí, María. 1988. "Relaciones sobre el estado de las Diócesis Hispanoamericanas». En Homenaje al Doctor Sebastià García Martínez, 447-461. Vol. I. Valencia: Universitat de València.

Cárcel Orti, Milagros y Vicente Cárcel Ortí. 1990. Historia, Derecho y Diplomática de la Visita ad limina. Valencia: Universitat de València.

Castillo Flores, José. 2016. «Los cabildos eclesiásticos en Nueva España. Letras, orígenes y movilidad, 1570-1600». En Poder y privilegio: cabildos eclesiásticos en Nueva España, siglos XVI a XIX, coord. Leticia Pérez Puente y Gabino Castillo Flores, 119-160. México: UNAM.
Cuevas, Mariano. 1924. Historia de la Iglesia en México (1600-1699). Tomo III. México: Imprenta del Asilo Patricio Sanz.

Duque Alcaide, Elisa. 2008. "Catecismos mexicanos de las primeras décadas de independencia 1810-1849». Anuario de Historia de la Iglesia 17: 43-61.

Enríquez Agrazar, Lucrecia. 2006. De colonial a nacional: la carrera eclesiástica del clero secular chileno entre 1650 y 1810. México: Instituto Panamericano de Geografía e Historia.

García Hourcade, José y Antonio Yrigoyen López. 2006. «Las visitas pastorales, una fuente fundamental para la historia de Iglesia en la Edad Moderna». Anuario de Historia de La Iglesia 15: 293-301.

Granado Hijelmo, Ignacio. 2010. «El Régimen jurídico del Cabildo catedralicio Galagurritano hasta la codificación canónica de 1917». Kolakoricos 15: 37-96.

Le Goff, Jacques. 2003. En Busca de la Edad Media. México: Paidos.

Le Goff, Jacques. 2005. L'Uomo Medievale. Roma: Editoriale Laterza

Marín López, Rafael. 1997. «Sobre los pecados públicos en la Granada Moderna». Chronica Nova 24: 337-347.

Marsiske, Renate. 2006. "La Universidad de México: Historia y Desarrollo». Revista Historia de la Educación Latinoamericana 8: 9-34

Martínez Cuesta, Ángel. 1995. "Las Monjas en la América Colonial: 1530-1824». Thesaurus: Boletín del Instituto Caro y Cuervo 50 (13), 572-626.

Mayer, Alicia. 2002. «El culto de Guadalupe y el proyecto tridentino en la Nueva España». Estudios de Historia Novohispana 26: 17-49.

Mazín, Oscar. 2016. «Cabildos Catedrales y republicas urbanas en Nueva España, siglos XVII y XVIII». En Poder y privilegio: cabildos eclesiásticos en Nueva España, siglos XVI a XIX, coord. Leticia Pérez Puente y Gabino Castillo Flores, 91-116. México: UNAM.

McCloskey, Michael OFM. 1955. The Formative Years of the Missionary College of Santa Cruz of Querétaro 1683-1733. Vol. II. Washington: Academy of American Franciscan History.

Metzler, Josef. 1997. «Reseña: America Pontificia III». Anuario de Historia de la Iglesia 6: 594-596.

Pérez Puente, Leticia. 2000. Universidad de Doctores. Siglo XVII. México: Centro de Estudios sobre la Universidad UNAM.

Pérez Puente, Leticia y José Castillo Flores, coords. 2016. Poder y privilegio: cabildos eclesiásticos en Nueva España, siglos XVI a XIX. México: Universidad Nacional Autónoma de México.

Reed, Benjamín. 2018. «Cultura de los Oratorianos en la Ciudad de México, 1659-1891: identidad corporativa, entre estructura y acción». Historia y Grafía 51: 15-52.

Ribot, Luis. 2019. La Edad Moderna (siglos XV-XVIII). Madrid: Marcial Pons Historia.

Ruiz-Gálvez Priego, Estrella. 2008. «Sine Labe. El inmaculismo en la España de los siglos XV a XVII: La proyección social de un imaginario religioso». Revista de Dialectología y Tradiciones Populares LXIII, 2: 197-241. https://doi.org/10.3989/rdtp.2008.v63.i2.62

Sassen, Saskia. 2009. Critique de L'État. Territoire, Autorité et Droits, de l'époque medievale à nos jours. París: Editions Demopolis.

Vargas Ugarte, Rubén. 1947. Historia del culto de María en Iberoamérica y sus imágenes y santuarios más celebrados. Buenos Aires: Editorial Huarpes. http://archive.org/details/historiadelculto00varg/ page/n839

Vargas Ugarte, Rubén. 1956. Historia del culto de María en Iberoamérica y sus imágenes y santuarios más celebrados. Madrid: Talleres gráficos Jura.

Vergara, Javier. 2005. «Datos y fuentes para el estudio de los seminarios conciliares en Hispanoamérica: 1563-1800». Anuario de Historia de la Iglesia 14: 239-300

Viqueira Albán, Juan. 2017. «Geografía religiosa del obispado de Chiapas y Soconusco (1545-1821)». EntreDiversidades. Revista de Ciencias Sociales 9: 147-207

Zarate Quevedo, Mariana. 2016. «Vida cotidiana en el Convento de Santa Catalina de Siena de Valladolid. (1734-1800)». En Primer Coloquio de historiadores «El Obispado de Michoacán: evangelización, espacio, economía, arte y cultura». Ucareo. Michoacán. 
